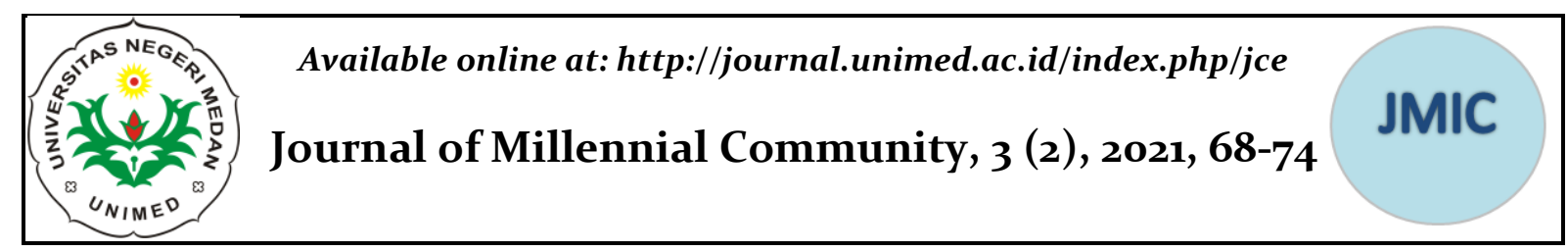

\title{
Peran Kewirausahaan Berbasis Digital Dalam Mengurangi Tingkat Pengangguran
}

\author{
Isra Mirna Noventri ${ }^{1 *}$, Juli Perawitan Pakpahan², Juli Wardani Pane, Lia Hutabarat ${ }^{4}$ \\ ${ }^{12}$ Pusat Kegiatan Belajar Masyarakat Optima, Sumatera Utara \\ 34 Pusat Kegiatan Belajar Masyarakat Ayah Bunda, Tapanuli Utara \\ Email : hutabaratliaıß@gmail.com
}

\begin{abstract}
Abstrak
Penciptaan wirausaha (entrepreneur) menjadi alternatif solusi atas berbagai masalah di masyarakat seperti kemiskinan dan kesenjangan sosial, meningkatnya pengangguran usia produktif dan menipisnya cadangan pasokan energi, yang kesemuanya menuntut adanya tindakan kreatif dan inovatif. Kewirausahaan adalah orang-orang yang mampu mengubah sebuah kesempatan menjadi sebuah usaha yang menghasilkan, yang diolah melalui kreatifitas, inovasi dan keunikan dalam membuat suatu produk dan berani mengambil segala kemungkinan resiko yang menyertainya serta tidak menjadikannya mudah putus asa jika mengalami kegagalan dalam membangun usaha tersebut. Dalam hal ini penulis mengkaji bahwa kewirausahaan turut berpartisipasi dalam pembangunan Negara, kewirausahaan berbasis digital memanfaatkan teknologi yang semakin canggih, kewirausahaan berbasis digital sebagai solusi dalam mengurangi tingkat pengangguran, banyaknya pengangguran di Indonesia, kewirausahaan adalah sesuatu yang harus ditanamkan oleh para pemuda dan masyarakat Indonesia.
\end{abstract}

Kata Kunci : Kewirausahan, Digital, Pengangguran

\section{The Role Of Digital Based Entrepreneurs In Reducing The Unemployment Level}

\begin{abstract}
Entrepreneurial creation becomes an alternative solution to various problems in society such as poverty and social inequality, increasing unemployment of productive age and depletion of energy supply reserves, all of which require creative and innovative action. Entrepreneurship is people who are able to turn an opportunity into a business that produces, which is processed through creativity, innovation and uniqueness in making a product and dare to take all possible risks that accompany it and not make it easy to despair if it fails to build the business. It was concluded that entrepreneurship also participated in the development of the State, digital-based entrepreneurship made use of increasingly sophisticated technology, digital-based entrepreneurship as a solution to reduce the unemployment rate, the number of unemployment in indonesia, entrepreneurship is something that must be instilled by the youth and the people of indonesia.
\end{abstract}

Keywords: entrepreneurship, digital, unemployment. 


\section{PENDAHULUAN}

Permasalahan ketenagakerjaan secara langsung maupun tidak langsung salah menyebabkan timbulnya pengangguran. Hal ini akan berkaitan dengan masalah-masalah lainnya seperti ketidakmerataan pendapatan, kemiskinan, perlambatan pertumbuhan ekonomi, urbanisasi, dan instabilitas politik (Siti Martiah,2017: 76 ). Semua ini secara intuitif tampaknya telah dipahami oleh para pengambil kebijakan. Oleh karena itu, berbagai upaya terus dilakukan pemerintah dalam rangka meningkatkan kesempatan kerja untuk mengurangi jumlah pengangguran yang berimplikasi terhadap lambatnya laju pertumbuhan ekonomi, mengingat semakin meningkatnya jumlah angkatan kerja baru yang memasuki pasar kerja.

Sedangkan penciptaan wirausaha (entrepreneur) menjadi alternatif solusi atas berbagai masalah di masyarakat seperti kemiskinan dan kesenjangan sosial, meningkatnya pengangguran usia produktif dan menipisnya cadangan pasokan energi, yang kesemuanya menuntut adanya tindakan kreatif dan inovatif. Jiwa kewirausahaan bukan hanya sebatas kecerdasan akademik dan keterampilan menghasilkan produk tetapi juga jiwa dinamis dalam menangkap tantangan dan resiko kemudian mengubahnya menjadi peluang dan potensi pertumbuhan (Soegoto 2009, dalam Herwin Moppangga, 2015).

Lebih lanjut dikemukakan bahwa entrepreneur mulai berkembang bukan hanya berdasarkan pada imitasi belaka, melainkan sudah mengikuti pada tiga tahapan spektrum, yaitu spectrum invensi, inovasi serta imitasi. Spektrum invensi merupakan tataran entrepreneur yang paling tinggi, setelah inovasi dan imitasi dimana pada spectrum imitasi pelaku bisnis hanya mendasarkan pada meniru produk atau bisnis yang sudah ada untuk mendapatkan bagian pasar dari produk tersebut. Sementara spectrum inovasi dimaknai sebagai kegiatan berentrepreneur dengan sentuhan-sentuhan perubahan pada berbagai aspek, sehingga menimbulkan nilai

memecahkan baru. Bahkan pandangan yang dikemukakan Bryd \& Brown (2003) dalam (Siti Martiah, 2017:76) bahwa inovasi bisa dilakukan secara incremental maupun radikal. Spektrum akhir adalah invention atau menemukan sesuatu yang baru yang benar-benar belum diketemukan.

Untuk meningkatkan minat berwirausaha/entrepreneur salah satunya adalah dengan meningkatkan pemahaman dan minat masyarakat terhadap bidang wirausaha. Kegiatan wirausaha harus didorong dengan keberanian dan keuletan serta tekad yang kuat, karena berwirausaha pada dasarnya berhimpitan dengan ketidakpastian, dalam hal keberhasilan maupun kegagalan. Karena hanya dengan menggeluti usaha secara penuh keberanian dan beresiko tinggi maka usaha akan tumbuh berkembang.

Untuk itu Technopreneur adalah salah satu bagian dari perkembangan berwirausaha (entrepreneur) memberikan gambaran berwirausaha dengan menggunakan inovasi basis technologi. Konsep technopreneur didasarkan pada basis tekhnologi yang dijadikan sebagai alat berwirausaha, misalnya munculnya bisnis aplikasi online, bisnis security system, dsb.

Technopreneurship berasal dari gabungan kata "technology" dan "entrepreneurship" (Depositario, et al., 2011). Technopreneurship merupakan proses sinergi dari kemampuan yang kuat pada penguasaan teknologi serta pemahaman menyeluruh tentang konsep kewirausahaan (Sosrowinarsidiono, 2010) dalam (Siti Martiah, 2017:76). Sudarsih dalam Prosiding KNIT RAMP-IPB (2013:57) mengemukakan bahwa technopreneurship adalah proses dan pembentukan usaha baru yang melibatkan teknologi sebagai basisnya dengan harapan bahwa penciptaan strategi dan inovasi yang tepat kelak bisa menempatkan teknologi sebagai salah satu faktor untuk pengembangan ekonomi nasional. Pendapat lainnya menyebutkan bahwa technopreneurship adalah proses dalam sebuah organisasi yang mengutamakan inovasi dan secara terus menerus menemukan problem utama organisasi,

mengimplementasikan cara-cara pemecahan 
masalah dalam rangka meningkatakan daya saing di pasar global (Okorie, 2014) dalam (Siti Martiah, 2017:77). Dari pandangan

pandangan diatas maka technopreneurship pada intinya akan menggabungkan antara teknologi dan kewirausahaan.

Dengan melakukan kajian terhadap peraturan dan kebijakan terkait kewirausahaan berbasis technology digital di Indonesia serta fakta -fakta yang berasal dari data sekunder yang berasal dari instansi tekait, tulisan ini diharapkan dapat menjadi sebuah gambaran tentang pentingnya technoprenuership melalui dunia usaha.

\section{PEMBAHASAN}

\section{Pengertian kewirausahaan}

Zimmerer mengartikan kewirausahaan sebagai suatu proses penerapan kreativitas dan inovasi dalam memecahkan persoalan dan menemukan peluang untuk memperbaiki kehidupan (usaha). Dalam Instruksi Presiden (Inpres) Nomor 4 tahun 1995 tanggal 30 Juni 1995 tentang Gerakan Nasional Memasyarakatkan dan Membudayakan Kewirausahaan, bahwasanya ; "Kewirausahaan adalah semangat, sikap, perilaku dan kemampuan seseorang dalam menangani usaha dan kegiatan yang mengarah pada upaya mencari, menciptakan, menerapkan cara kerja, teknologi dan produksi baru dengan meningkatkan efisiensi dalam rangka memberikan pelayanan yang lebih baik dan atau memperoleh keuntungan yang lebih besar.

Sedangkan menurut Robbin dan Coulter, kewirausahaan adalah sebuah proses dimana seseorang atau kelompok orang menggunakan segala daya upayanya yang terorganisasi untuk mencari sebuah peluang dan menciptakan sesuatu yang memiliki daya guna serta manfaat yang bersumber dari inovasi dan keunikan tanpa memperhatikan sumber daya yang digunakan saat itu.

Jadi Kewirausahaan adalah orang orang yang mampu mengubah sebuah kesempatan

Berdasarkan data di atas, terlihat bahwa jumlah pengusaha di Indonesia masih sedikit karena masih di bawah $2 \%$. Selanjutnya sampai tahun 2017, rasio pengusaha di Indonesia sudah naik menjadi 3,1\%. Hal ini sesuai dengan pernyataan dari Bapak menjadi sebuah usaha yang menghasilkan, yang diolah melalui kreatifitas, inovasi dan keunikan dalam membuat suatu produk dan berani mengambil segala kemungkinan resiko yang menyertainya serta tidak menjadikannya mudah putus asa jika mengalami kegagalan dalam membangun usaha tersebut.

Dalam rangka turut berpartisipasi dalam pembangunan negara, sebagai warganegara harusnya ikut andil, apapun profesinya. Hal ini bisa dilakukan dengan turut mendukung program pemerintah. Salah satu program pemerintah yakni meningkatkan jumlah wirausahawan untuk mendukung visi Indonesia menjadi Negara maju di tahun 2045. Salah satu indicator negara maju adalah terciptanya lapangan pekerjaan yang lebih banyak. Hal ini tidak mungkin terjadi jika para lulusan dari perguruan tinggi bergantung pada lapangan pekerjaan yang dibuka oleh pemerintah. Untuk mewujudkan visi tersebut, Indonesia harus menambah jumlah pengusaha (wirausahawan) yang tidak hanya bergantung pada aspek sumberdaya alam tapi juga mampu bergerak di bidang industri. Jika dibandingkan dengan negara negara lain di dunia, maka jumlah wirausahawan di Indonesia masih tergolong sedikit.

Gambar 1. Data Rasio Pengusaha Terhadap Jumlah Penduduk Di Beberapa Negara 2013

Resio Ponounahe Tertusap Jumbiah

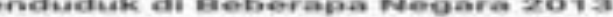

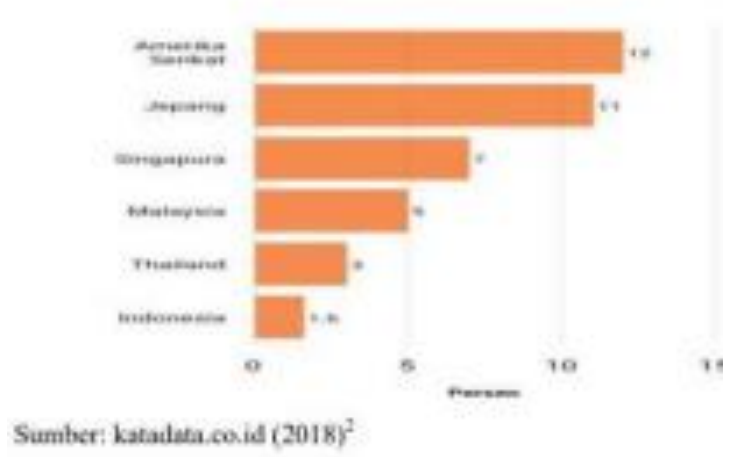

Puspayoga selaku Menteri Koperasi dan UKM dalam acara Gerakan Kewirausahaan Nasional (GKN) 2017 di Institut Pertanian Bogor (IPB) pada Maret 2017. Beliau mengatakan: "rasio wirausaha Indonesia yang pada 2013/2014 lalu masih 1,67\% kini 


\section{Journal of Millennial Community, 3 (2), September 2021}

Isra Mirna Noventri, Juli Perawitan Pakpahan, Juli Wardani Pane, Lia Hutabarat

berdasarkan data BPS naik menjadi 3,1\%” . Meskipun sudah mengalami peningkatan, jumlah wirausahawan di Indonesia masih jauh di bawah negara negara lainnya. Hal ini terlihat dari pernyataan presiden Republik Indonesia, Bapak Joko Widodo: "hampir di setiap Negara maju, standarnya itu memiliki (penduduk) entrepreneur di atas $14 \%$. Sementara kita, angkanya masih 3,1\%. Artinya perlu percepatan".

\section{Kewirausahaan berbasis digital}

Istilah technopreneurship atau kewirausahaan digital didefinisikan pemanfaatan teknologi pada kegiatan berwirausaha. Pemanfaatan teknologi dalam hal ini dipahami mulai dari proses produksi (dengan mesin dan teknologi terbarukan) hingga pemasaran (memanfaatkan media sosial, platform online, aplikasi, dan lain lain). Istilah lain yang lebih umum digunakan oleh generasi millennial adalah start-up atau bisnis pemula. Start-up pada dasarnya aktivitas perintisan bisnis yang memiliki model bisnis yang terencana dan memanfaatkan teknologi dalam bentuk platform dana atau aplikasi.

Kewirausahaan merupakan kemampuan mengubah setiap peluang menjadi tantangan yang bernilai ekonomi. Saat kemampuan ini disinergikan dengan kompetensi di bidang teknologi, maka lahirlah kemampuan wirausaha di bidang teknologi yang lazim dikenal sebagai technopreneurship. Suparno menjelaskan technopreneurship bersumber dari riset dan temuan-temuan baru dalam bidang teknologi yang dikembangkan dengan saksama, sehingga dapat memberikan

keuntungan bagi penciptanya dan masyarakat penggunanya. Penggiat

\section{Pengangguran}

Pengangguran merupakan suatu ukuran yang dilakukan jika seseorang tidak memiliki pekerjaan tetapi mereka sedang melakukan usaha secara aktif dalam empat minggu terakhir untuk mencari pekerjaan (Kaufman dan Hotchkiss, 1999). Sedangkan menurut Sukirno (2006:13) pengangguran adalah suatu keadaan dimana seseorang yang tergolong dalam angkatan kerja yang ingin technopreneurship disebut sebagai wirausaha digital.

Data dari We Are Social dan Hootsuite menyebutkan bahwa Indonesia merupakan negara dengan pertumbuhan internet terbesar di dunia, yaitu sebesar $51 \%$ dalam kurun satu tahun terakhir. Angka ini jauh dari rata-rata pertumbyhage|71 internet global yang hanya sebesar 10\%.vi Indonesia juga berada dalam 12 besar negara di dunia dengan penetrasi penggunaan telepon pintar terbesar di dunia. vii Angka ini menunjukkan potensi yang besar jika pelaku bisnis dapat memulai go digital. 9 Masyarakat di era digital pada umumnya cenderung menginginkan inovasi dan kemudahan dalam kehidupan seharihari. Hadirnya platform jual beli online, media sosial, dan transaksi pembayaran secara elektronik pilihan yang efisien bagi masyarakat.

Kehadiran wirausaha digital berpotensi memunculkan perusahaan rintisan (startup company) yang sering kali membuat terobosanterobosan melalui teknologi disruptif (disruptive technology). Kehadiran perusahaan jenis ini dirasakan sangat membantu konsumen, karena umumnya menawarkan solusi berupa kemudahan dan kenyamanan dengan harga/ tarif yang lebih murah. Kemunculan wirausaha digital di Indonesia tentunya akan menarik banyak aktivitas ekonomi yang pada akhirnya berpotensi meningkatkan kualitas hidup masyarakat.
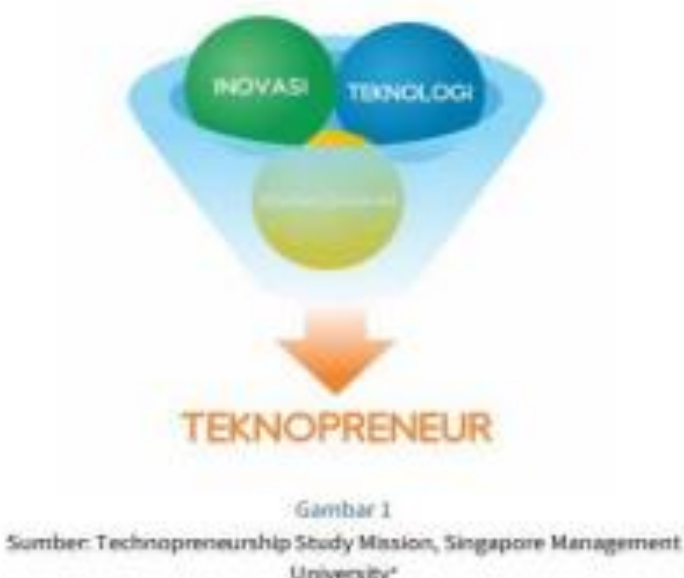

mendapatkan kerja tetapi mereka belum dapat memperoleh pekerjaan tersebut. Pengangguran dapat terjadi disebabkan oleh ketidakseimbangan pada pasar tenaga kerja. Hal ini menunjukkan bahwa jumlah tenaga kerja yang ditawarkan melebihi jumlah tenaga kerja yang diminta. 


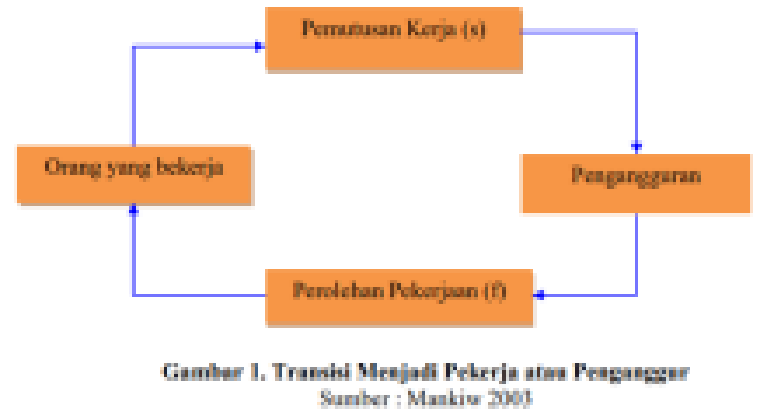

Pada Teori Klasik dijelaskan ada dua alasan yang menyebabkan terjadinya pengangguran yaitu:

1. Kekakuan Tingkat Upah. Serikat serikat buruh tidak bersedia menerima tingkat upah yang lebih rendah, ketika mereka bersedia menerima tingkat upah yang lebih rendah, maka permintaan terhadap tenaga buruh akan meningkat, sehingga pengangguran dapat diturunkan.

2. Kekakuan yang kedua muncul dari pihak pengusaha besar, yang meningkat kekuatan monopolinya, sehingga mereka lebih leluasa menentukan tingkat harga pasar.

Tingkat Pengangguran Terbuka (TPT) adalah indikator yang dapat digunakan untuk mengukur tingkat penawaran tenaga kerja yang tidak digunakan atau tidak terserap oleh pasar kerja. TPT pada Februari 2017 sebesar 5,33 persen turun menjadi 5,13 persen pada Februari 2018. Dilihat dari daerah tempat tinggalnya, TPT di perkotaan tercatat lebih tinggi dibanding di perdesaan. Pada Februari 2018, TPT di perkotaan sebesar 6,34 persen, sedangkan TPT di wilayah perdesaan hanya sebesar 3,72 persen. Dibandingkan setahun yang lalu, TPT di perkotaan dan TPT di perdesaan mengalami penurunan masing masing sebesar 0,16 persen poin dan 0,28 masyarakat yang penangguran, dimana dengan memberikan bekal pengetahuan, keterampilan serta menumbuhkan sikap kewirausahaan pada para pencari kerja melalui pengembangan

kewirausahaan. Menurut Gerakan Nasional Memasyarakatkan dan Membudayakan Kewirausahaan (GNMMK), yang dimaksud kewirausahaan adalah semangat, sikap, perilaku dan kemampuan seseorang dalam menangani usaha dan atau kegiatan yang mengarah pada upaya mencari, menciptakan, menerapkan persen poin.

\section{Peran wirausaha berbasis digital untuk mengurangi tingkat pengangguran}

Pengangguran yang terjadi di indonesia merupakan masalah yang kompleks dan bersifat multidimensional. Faktor terjadinya pengangguran adalah ketidkaseimbangan Page | antara lapangan pekerjaan dengan jumlah 72 tenaga kerja -- adanya perubahan tekhnologi - kurangnya pendidikan dan keterampilan banyaknya kemiskinan- dan lainlain. Banyak

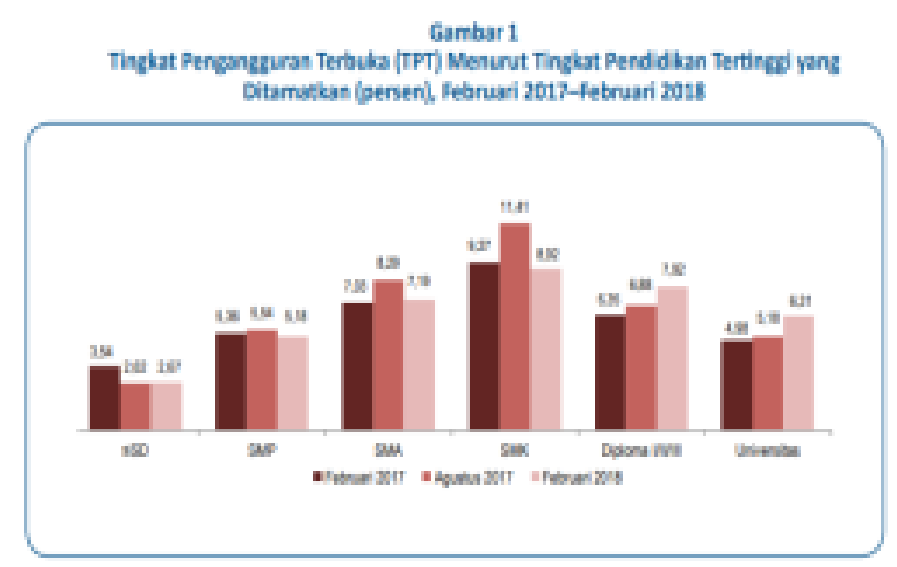

peluang untuk melakukan kegiatan ekonomi khususnya dibidang usaha. Namun masyarakat indonesia masih banyak yang kurang menyadari itu, masyarakat banyak yang menginginkan bekerja di perusahaan perusahaan yang ternama demi dipandang keren dan hebat.

Dengan adanya atau banyaknya angka pengangguran di Indonesia maka solusi yang dapat diberikan yaitu dengan memberikan pengetahuan mengenai kewirausahaan berbasis digital, dimana para masyarakat dapat membuka suatu usaha yang dapat menambah pendapatan dan dapat membuka lapangan kerja. Sehingga dapat menampung

acara kerja, teknologi dan produk baru dengan meningkatkan efisiensi dalam rangka memberikan pelayanan yang lebih baik dan atau memperoleh keuntungan yang lebih besar.

Untuk mengurangi tingkat pengangguran perlu ditanamkan sikap mental wirausaha sehingga pada diri mereka akan tertanam ciri dan watak wirausaha yang akan mendasari setiap perilaku kehidupannya. Melalui pengembangan kewirausahaan diharapkan para penganggur berani 
melakukan usaha sendiri sehingga dapat menciptakan lapangan kerja baik untuk diri sendiri maupun orang lain.

Wirausaha merupakan suatu hal yang harus ditanamkan oleh para pemuda dan masyarakat Indonesia. Karena dengan wirausaha masyarakat mampu membuka lapangan pekerjaan untuk masyarakat yang tidak memiliki pekerjaan atau pengangguran. Membuka usaha pribadi, sekecil apapun usaha yang anda miliki, andalah yang menjadi pemimpin roda usaha tersebut. Ketika usaha anda berjalan dengan baik, maka anda dapat memperbaiki perekonomian negara, minimal masyarakat disekitar lingkungan ada memiliki pengasilan dengan usaha yang anda buat. Menjadi seorang Wirausaha merupakan kegiatan bisnis yang mulia, memang untuk memulai satu usaha sendiri tidaklah mudah, tapi seorang yang memiliki jiwa wirausaha pasti orang tersebut mampu menaklukan ketakuan- ketakuan yang ada dalam dirinya. Serta ia mampu menghadapi tantangan tantangan yang terjadi dikemudian hari.

Dengan adanya pembukaan suatu usaha akan menambah peluang atau kesempatan bagi masyarakat untuk bekerja dan menambah pendapatan. Kesempatan kerja akan terjadi apabila laju ekonomi mengalami kenaikan sebagai akibat makin tingginya ilktivitas ekonomi yang memerlukan tambahan tenaga kerja. Secara teori, setiap laju pertumb.uhan ekonomi sebesar 1 (satu) persen akan mampu menyerap tenaga kerja sebesar 400.0oo orang. Jika setiap tahun terjadi tambahan angkatan kerja baru 2,3 juta orang maka untuk menyerap tambahan angkat kerja baru berkembangnya bisnis pemula. Pelaku bisnis lokal serta merta dapat menjangkau pasar yang lebih luas melalui personalisasi aplikasi dan layanan serta kemudahan konektivitas.

Terkait dengan hal itu kewirausahaan berbasis digital ini dapat memperluas jangkauan penjualannya dan dengan mudah orang-orang akan mengetahui terkait penjualan barang tersebut, sehingga target atau keuntungannya lebih banyak.

Pengembangan berbagai lembaga riset, pusat inovasi dan inkubator bisnis ini juga dalam bidang teknologi di tingkat pendidikan tinggi (Akademi/ Institut/ Universitas) merupakan upaya positif untuk membangun maka laju pertumbuhan ekonomi harus diusahakan sebesar 6\% (Sukidjo, 2003: 425). Untuk mengembangkan suatu wirausaha maka dapat dilakukan dengan memanfaatkan teknologi yang semakin canggih, dimana dalam hal ini dapat membuat suatu wirausaha yang berbasis digital. Teknologi merupakan cara atau metode untuk mengolah sesuatu agar terjadi efisiensi biaya dan waktu, sehingga dapat menghasilkan produk yang lebih berkualitas. Dasar-dasar penciptaan tekologi adalah: kebutuhan pasar, solusi atas permasalahan, aplikasi berbagai bidang keilmuan, perbaikan efektivitas dan efisiensi produksi, serta modernisasi. Perkembangan teknologi digital dan digitalisasi telah memungkinkan perolehan informasi dan pengetahuan dengan cara yang mudah dan cepat, sehingga dengan demikian dapat dikatakan bahwa dewasa ini setiap individu memiliki peluang yang relatif sama terhadap informasi dan pengetahuan.

Digitalisasi adalah kemampuan untuk merubah produk atau jasa yang ada ke dalam bentuk digital sehingga menawarkan keuntungan yang melebihi produk berwujud'. Secara lebih ringkas Brennen dan Kreiss (2014) dalam Nia (2018:7) menyatakan bahwa digitalisasi berkaitan dengan adopsi atau peningkatan penggunaan teknologi digital atau komputer oleh organisasi, industri, negara, dan sebagainya.

Teknologi digital yang secara praktis mewujudkan dalam pertumbuhan fungsi serta peran teknologi informasi dan komunikasi (ICT) menjadi pendorong pertumbuhan bisnis dan memungkinkan ekosistem kewirausahaan digital. Melalui kewira-usahaan dalam bidang teknologi, pembangunan yang berkelanjutan sebuah negara, bahkan dunia, dapat terwujud. Beberapa wirausaha digital yang dapat dikatakan sukses dalam meraih keuntungan sekaligus memberi warna baru terhadap kehidupan masyarakat dunia, antara lain: Mark Zuckerberg (Pendiri Facebook), Steve Jobs (Pendiri Apple), Jan Koum dan Brian Acton (Pendiri Whatsapp), dan lain-lain. Indonesia pun telah memiliki sejumlah wirausaha digital, seperti: Andrew Darwis (Pendiri Kaskus), William Tanuwijaya (Pendiri Tokopedia), Nadiem Makarim 
Journal of Millennial Community, 3 (2), September 2021

Isra Mirna Noventri, Juli Perawitan Pakpahan, Juli Wardani Pane, Lia Hutabarat

(Pendiri GO-JEK), dan sebagainya.

\section{SIMPULAN}

Berdasarkan pembahasan di atas dapat disimpulkan bahwa (1) kewirausahaan turut berpartisipasi dalam pembangunan Negara, (2) kewirausahaan berbasis digital memanfaatkan teknologi yang semakin canggih, (3) kewirausahaan berbasis digital sebagai solusi dalam mengurangi tingkat pengangguran, (4) banyaknya pengangguran di Indonesia, (5) kewirausahaan adalah sesuatu yang harus ditanamkan oleh para pemuda dan masyarakat Indonesia. Demikian kesimpulan dari kajian pembahasan terkait peran keirausahaan berbasisi digital untuk mengurangi tingkat pengangguran. Kurang dan lebihnya penulis memohon saran dan kritik yang membangun agar proses pembuatan artikel ini dapat berlanjut sebagai modal pengembangan keilmuan.

\section{DAFTAR PUSTAKA}

Clelland, David MC. (1961). Entrepreneur Behavior And Characteristics Of Entrepreneurs. The Achieving Society.

Hartanti. (2008). "Manajeme pengembangan kewirausahaan (entrepreneurship) siswa SMK 4 Yogyakara." Universitas Negeri Yogyakarta.

Kaufman, Bruce E. And L. Hotchkiss. (1999).The Economic Labor Markets. USA: Georgia State University

Sukirno, Sadono. (2006). Makroekonomi Teori Pengantar. Jakarta: PT RajaGrafindo Persada

Soekidjo, Notoatmodjo. (2003) .Pengembangan Sumber Daya Manusia. Jakarta: PT Rineka Cipta

Anata, Firdaus, (2013), Pengaruh Tingkat Pengangguran Terbuka, PDRB Perkapita, Jumlah Penduduk dan Indeks Williamson Terhadap Ttingkat Kriminalitas(Studi pada 31 Propinsi di Indonesia tahun 2007 - 2012), Jurnal Ilmiah Fakultas Ekonomi Dan Bisnis, Universitas Brawijaya, Malang.

Aruan, Norman Luther dan D Sriyono.(2014).Faktor-Faktor Yang
Mempengaruh Tingkat Pengangguran di Daerah Istimewa Yogyakarta (DIY) Tahun 1985- 2011. Yogyakarta : MODUS Vol.26 (2): 173-187,

Estiningsih, Wening. Zainal, Arifin, HM, (2014), Technoprenuership;Challenge For Entrepreneurship Educational Development in Indonesia, Forum Tahunan Pengembangan Iptek dan Inovasi Nasional IV, LIPI, Tahun (2014).

Herwin Moppanga, Studi Kasus Pengembangan Wirausaha Berbasis Tekhnologi (Technopreneurship) di Provinsi Gorontalo, Journal Trikonomika, Volume.14 no.1 TH.(2015)

Nia, Juliawati. (2018). Membangun Kewirausahaan: antara Digital Economy dan Human Economy

Siti Marti'ah, (2017). Kewirausahaan Berbasis Teknologi (Technopreneurship) dalam Perspektif Ilmu Pendidikan. Jakarta. Jurnal Ilmiah Edutic . 3(2). 75-82

Instruksi Presiden Republik Indonesia No. 4 Tahun 1995 Tentang Gerakan Nasional Memasyarakatkan dan Membudayakan Kewirausahaan (GNMMK)

Jamaludin, Fauzan. Ini tahapan-tahapan

Kementerian Komunikasi dan Informasi, kominfo (daring),, "Kominfo Luncurkan Gerakan Nasional 1000 Start Up Digital
Page | 74 
Journal of Millennial Community, 3 (2), September 2021

Isra Mirna Noventri, Juli Perawitan Pakpahan, Juli Wardani Pane, Lia Hutabarat 